\title{
GŁÓWNE TEMATY TEOLOGICZNE DRUGIEGO LISTU ŚW. PIOTRA
}

Kościół jest wspólnotą osób w drodze, podążających na spotkanie Pana, który w ustalonym przez Boga dniu przyjdzie w chwale $\mathrm{i}$-jak sam zapowiedział (zob. np. Mt 25,31-46) - dokona sądu nad wszystkimi narodami, by pokazać, kto jest w pełni godny wejść do Jego królestwa. To właśnie oblicze Kościoła, niekiedy zapominane przez chrześcijan, usiłuje przypomnieć autor Drugiego Listu św. Piotra. ${ }^{1}$ W Kościele pierwotnym list ten spotykał się często z nieufnością niektórych chrześcijan i musiał długo czekać, aż uzyskał powszechne uznanie i został włączony do kanonu ksiąg natchnionych. Trzeba jednak stwierdzić, że zawiera on wielkie bogactwo wzniosłej myśli teologicznej, która zasługuje na uznanie i większe zainteresowanie. Należą do niej następujące tematy: autorytet Pisma Świętego i właściwa jego interpretacja, boski autorytet Jezusa Chrystusa (chrystologia), zbawcza wola Boga i Jezusa Chrystusa (soteriologia), obietnica powtórnego przyjścia Pana (eschatologia) oraz życie moralne oparte na Ewangelii.

\section{Autorytet Pisma Świętego i wlaściwa jego interpretacja}

W Drugim Liście św. Piotra jest mowa o autorytecie Pisma Świętego $\mathrm{w}$ dwóch fragmentach. W pierwszym z nich autor oświadcza,

1 Problem autorstwa tego listu był przedmiotem dyskusji już od czasów starożytnych i do dzisiejszego dnia nie został jednoznacznie rozwiązany. Dyskusję tę omawia każdy komentarz do Drugiego Listu św. Piotra, dlatego w tym artykule zostało świadomie pominięte to zagadnienie. Niezależnie od tego, czy list ten został napisany przez samego apostoła Piotra, czy też został zredagowany przez jego ucznia na podstawie jego nauki, autora listu będziemy nazywali Piotrem. 
że, ,żadne proroctwo Pisma nie jest do prywatnego wyjaśnienia. Nie z woli bowiem ludzkiej zostało kiedyś przyniesione proroctwo, ale kierowani Duchem Świętym mówili od Boga ludzie" (2P 1,20-21). $\mathrm{W}$ drugim fragmencie natomiast pisze o listach, których autorem jest „umiłowany nasz brat, Paweł”, oraz o pozostałych Pismach, „ludzie niedouczeni i mało utwierdzeni opacznie tłumaczą, tak samo jak i inne Pisma, na własną swoją zgubę" $(3,16)$.

Ukazując autorytet proroctwa biblijnego, Piotr nawiązuje zarówno do znanej mu tradycji żydowskiej, która uznawała autorytet Prawa i pism prorockich, jak też do rodzącej się dopiero tradycji chrześcijańskiej. Czytane w świątyni w określone święta oraz w czasie liturgii synagogalnej księgi Żydzi otaczali wręcz religijną czcią, traktowali je jak żywe słowo Boże i uważali za święte. ${ }^{2}$ Chrześcijanie natomiast, którzy na początku wywodzili się w większości ze środowiska żydowskiego, potwierdzali autorytet Prawa i Proroków, pamiętając o tym, że sam Jezus uważał te pisma za słowo Boże, którego nie można odrzucić i które przygotowywało naród wybrany na Jego przyjście (zob. m.in. Łk 24,27; J 10,34-35). Kiedy zaś apostołowie i ich uczniowie zaczęli pisać listy oraz spisywać swe wspomnienia o Jezusie Chrystusie (Ewangelie), również te dzieła szybko uznano za wiarygodne przedłużenie lub wyjaśnienie nauki samego Chrystusa, a tym samym za godne czci i religijnego szacunku. Uważano bowiem, że zarówno Mojżesz, prorocy, psalmiści i mędrcy, jak też dwunastu apostołów Jezusa, świadomie lub nieświadomie odegrali rolę Bożych wysłanników, dzięki którym Boże słowo dotarło do szerokich rzesz czytelników. ${ }^{3}$

Dokonując refleksji nad rangą ksiąg uznawanych za święte, Piotr pisze o kierowaniu pisarzy biblijnych przez Ducha Świętego (2P 1,16-21). W tekście tym nie głosi on całkowicie nowej nauki, lecz z tradycji judaistycznej przejmuje ideę Ducha proroctwa i łączy ją z prorokami

2 Zob. szerzej J. M a i e r, Między Starym a Nowym Testamentem. Historia i religia w okresie Drugiej Świątyni, Kraków 2002, s. 16-17.

3 Por. L.A. S c hö k e 1, Stowo natchnione. Pismo święte w świetle nauki o języku, Kraków 1983, s. 54-55. 
starotestamentowymi, którzy głosili słowo mocą Ducha Bożego (zob. np. Iz 42,1; 48,16; 59,21; 61,1; Ez 11,5; 37,5-14; J1 3,1; Mi 3,8; Za 7,12). Nawiązując do tej tradycji, Piotr jest przekonany, że ten sam Duch Święty stał się również dla apostołów mocą dającą zarówno natchnienie, jak też zdolność głoszenia z przekonaniem skłaniającym słuchaczy do przyjęcia ich świadectwa i do nawrócenia. Mając świadomość niezastąpionej roli Ducha Świętego w tworzeniu Pisma Świętego, Piotr z wielkim szacunkiem wspomina listy Pawła, który napisał je „według danej mu mądrości” (2P 3,15). Ponadto czyni aluzję do Pierwszego Listu św. Piotra, przypominając swym adresatom, że jest w nim zawarte wiarygodne nauczanie apostolskie (3,1-2). Należy tu dodać, że w 3,16 zestawia listy Pawła z pozostałymi Pismami i stwierdza, wszystkie one mają ten sam niekwestionowany autorytet. Większość egzegetów uważa, że „inne Pisma” (tas loipas grafas) oznaczają księgi Starego Testamentu, niektórzy jednak sugerują, że być może Piotr ma tu na uwadze znane mu księgi nowotestamentowe, np. List św. Judy, z którego korzystał, Pierwszy List św. Piotra, pierwotną wersję Ewangelii św. Mateusza, która - według świadectwa Papiasza - zawierała mowy Pańskie ${ }^{4}$ oraz Ewangelię św. Marka, ${ }^{5}$ która w tym czasie była już rozpowszechniona w Kościele. Niezależnie od tego, co one oznaczają, można stwierdzić, że Drugi List św. Piotra jako pierwszy wyraźnie świadczy o początkach procesu kanonizacji Nowego Testamentu. ${ }^{6}$

Autor listu jest zatem przekonany, że słowo spisane w Piśmie Świętym nie jest dziełem ludzkim, lecz pochodzi od Boga i jest słowem samego Boga, a tym samym jest pewne i wiarygodne. $Z$ tego wyciąga wniosek, że czytelnicy powinni nim żyć, kierować się nim w swym życiu duchowym, traktować je jak światło oświecające drogę życia

4 Eu ze bius z z Cezarei, Historia kościelna 3, 39, 16.

5 Por. H. L a n g a m m e r, Listy Katolickie. List św. Jakuba, Pierwszy List św. Piotra. Drugi List św. Piotra. List św. Judy, Biblia Lubelska, Lublin 2016, s. 209.

${ }^{6}$ Odnośnie do tego szerzej pisze J.-N. A 1 e $\mathrm{t} \mathrm{t}$ i, La seconde épître de Pierre et le Canon du NT, w: Ch. T h e o b a ld (red.), Le canon des écritures. Etudes historiques, exégétiques et sistématiques, Lectio Divina 140, Paris 1990, s. 239-253. 
religijnego i moralnego oraz odwoływać się do niego w zmaganiach z fałszywymi nauczycielami (2P 1,19b). Jest przy tym oczywiste, że Pismo Święte ze względu na jego autorytet „nie jest do prywatnego wyjaśnienia" (2P 1,20), jeśli zaś ktoś tłumaczy je opacznie, czyli niezgodnie z duchem, w którym zostało napisane, sam siebie prowadzi do zguby $(3,16)$. Egzegeci wyjaśniają sens tej wypowiedzi na kilka różnych sposobów.

I. Pismo Święte nie powinno być interpretowane w oderwaniu od nauczania Kościoła powszechnego i jego przewodnictwa. ${ }^{7}$ Teolodzy z tego grona widzą w Drugim Liście Piotra przejaw „wczesnego katolicyzmu” lub początek formowania się magisterium późniejszego Kościoła katolickiego. ${ }^{8}$

II. Piotr oświadcza w swym liście, że interpretacja biblijnego proroctwa nie może się opierać tylko na własnym, prywatnym, osądzie, lecz musi być szeroko akceptowana lub powinna stanowić część tradycji apostolskiej. ${ }^{9}$

III.Zdanie z 2P 1,20b należy przetłumaczyć: „Żadne proroctwo nie powstaje $\mathrm{z}$ własnej interpretacji”, ponieważ stanowi ono potwierdzenie Bożego pochodzenia proroctw biblijnych. ${ }^{10}$ Prorocy otrzymywali od Boga objawienie za pośrednictwem wizji, snów lub znaków, które same w sobie są ważne, ale bez

7 Zob. np. E. Käsemann, An Apologia for Primitive Christian Eschatology, w: tenże, Essays on New Testament Themes, Philadelphia 1982, s. 189-191; J.N.D. Kelly, A Commentary on the Epistles of Peter and of Jude, London 1969, s. 324; W. G r u n d m a n n, Der Brief des Judas und der zweite Brief des Petrus, Theologischer Handkommentar zum Neuen Testament 15, Berlin 1986³, s. 86; H. Paulsen, Der zweite Petrusbrief und der Judasbrief, Kritisch-exegetischer Kommentar über das Neue Testament 12/2, Göttingen 1992, s. 123-124; F. Gryglewicz, Listy Katolickie. Wstęp-przekład z oryginału - komentarz, Pismo Święte Nowego Testamentu 11, Poznań 1959, s. 283; H. Langkammer, Listy Katolickie, s. 191.

8 Tak określa ich B.M. F a n n i n g, Teologia Listów Piotra i Judy, w: R.B. Z u c k (red.), Teologia biblijna Nowego Testamentu, Warszawa 2010, s. 550.

9 E. B l u m, 2 Peter, w: F.E. G a e b e le i n (red.), The Expositor's Bible Commentary, Grand Rapids 1981, s. 275.

10 Por. R.A. R e e s e, 2 Peter and Jude, THNTC, Grand Rapids 2007, s. 144-145; C.P. G i e s e, 2 Peter and Jude, Saint Louis 2012, s. 87. 
zrozumienia ich znaczenia nie można zrozumieć całego orędzia Bożego. $Z$ tego powodu w drugiej kolejności Bóg objawiał prorokom również właściwy sposób interpretacji owej wizji lub znaku (tak jest np. w Rdz 40, 8; 41,8.12; Am 7-8; Jr 1; Dn 7-8). Oznacza to, że całe proroctwo, zarówno prorocza wizja, jak też jej interpretacja, pochodzi od Boga, z czego wypływa wniosek, że nigdy nie może być ono przedmiotem indywidualnej lub też prywatnej interpretacji, która często prowadzi do herezji. ${ }^{11}$ IV.W interpretacji Pisma Świętego należy wychodzić od samego tekstu biblijnego, który z woli Ducha Świętego pośredniczy w przekazaniu ludziom słowa samego Boga, udzielonego prorokom. Ponieważ zaś gwarantem autentyczności Pisma Świętego są apostołowie (por. 2P 1,19), wypływa z tego wniosek, że jego interpretacja nie może być dowolna, lecz musi być zgodna z nauczaniem wspólnoty apostolskiej. ${ }^{12}$

Odczytując tekst 2P 1, 20-21 w świetle czasów, w których został napisany, należy stwierdzić, że wtedy jeszcze nie było urzędu nauczycielskiego Kościoła lub oficjalnej, kościelnej wykładni Pisma Świętego. Autor tej wypowiedzi podkreśla przede wszystkim prawdę, że biblijne proroctwa mają pochodzenie Boże i zostały spisane pod natchnieniem Ducha Świętego. Ponieważ są w nich fragmenty bardzo niejasne i trudne do zrozumienia (nie tylko w listach św. Pawła, ale we wszystkich księgach biblijnych), powinny one stać się przedmiotem nieustannej medytacji, prowadzonej w świetle całego objawienia i pod kierownictwem Ducha Świętego, ${ }^{13}$ nigdy natomiast nie mogą

11 R. B a u c k h a m, Jude - 2 Peter, Word Biblical Commentary 50, Grand Rapids 1983, s. 232-233; B.M. F a n n i n g, Teologia Listów Piotra i Judy, s. 550-551; D. K e a $t$ i n g, First and Second Peter, Jude, Grand Rapids 2011, s. 153; G.L. G r e e n, Jude and 2 Peter, Grand Rapids 2008, s. 231; S.J. K r a f t c h i c k, Jude, 2 Peter, Nashville 2002, s. 117-118.

12 G. Ma r c o n i, Lettera di Giuda. Seconda Lettera di Pietro. Introduzione, versione, commento, Scritti delle Origini Cristiane 19, Bologna 2005, s. 152.

13 Por. K.H. S c h e 1 k l e, Die Petrusbriefe. Der Judasbrief, Herders theologi-scher Kommentar zum Neuen Testament 13/2, Freiburg 1965², s. 200. 
być przedmiotem ludzkich manipulacji, które prowadzą do wypaczenia orędzia Bożego i do herezji.

\section{Chrystologia i soteriologia}

Chrystologia Drugiego Listu św. Piotra świadczy o tym, że reprezentuje on daleko posunięty rozwój teologicznej myśli pierwotnego chrześcijaństwa. O jej wzniosłości świadczą przede wszystkim tytuły, które Piotr w swym piśmie nadaje Jezusowi Chrystusowi: ${ }^{14}$ „,nasz Bóg i Zbawiciel, Jezus Chrystus” (1,1); , Jezus, nasz Pan” (1,2); „,nasz Pan, Jezus Chrystus” (1,8.14.16); „nasz Pan i Zbawiciel Jezus Chrystus” $(1,11 ; 2,20 ; 3,18)$; „Pan i Zbawiciel” (3,2); „Władca, który ich nabył” $(2,1)$; „umiłowany Syn Boga” $(1,17)$.

Powyższe zestawienie pokazuje, że imię „Jezus”, które występuje w Drugim Liście św. Piotra aż 8 razy, prawie zawsze (tylko z wyjątkiem 1,2) z określeniem „Chrystus”. Określenie to nie jest już tylko jakimś dodatkiem ani nawet tytułem oznaczającym oczekiwanego Pomazańca Bożego, lecz stanowi drugi człon Jego pełnego imienia. ${ }^{15}$ Oczywiście, taki sposób nazywania Jezusa nie jest wymysłem samego Piotra (choć według Mk 8,29 właśnie on jako pierwszy wyznał wiarę w Niego jako Mesjasza). W Kościele pierwotnym nauczano, że Bóg uczynił Jezusa „i Panem, i Mesjaszem” (Dz 2,36), albowiem Go „namaścił Duchem Świętym i mocą” (Dz 10,38), powołując do wypełnienia Jego zbawczej woli. Tak więc chrześcijanie rozumieli tytuł „Chrystus” najpierw jako określenie powołania Jezusa, ale potem zaczęli go traktować jako drugie Jego imię. Jest to najbardziej widoczne w 1Kor 15,3, gdzie św. Paweł przytacza wyznanie wiary gminy jerozolimskiej, wymieniając tylko imię „Chrystus”. ${ }^{16} \mathrm{~W}$ tę tra-

14 Odnośnie do tego zob. F. G r y g l e w i c z, Rozwój teologii Listu św. Judy i Drugiego Listu św. Piotra, RBL 33/1980, s. 250-251; B.M. F a n n i n g, Teologia Listów Piotra i Judy, s. 523.

15 Por. P.H. D a v i d s, The Letters of 2 Peter and Jude, The Pillar New Testament Commentary, Grand Rapids 2006, s. 151.

16 Por. K.H. S c h e 1 k 1 e, Teologia Nowego Testamentu, t. 2: Bóg byt w Chrystusie, Kraków 1984, s. 199. 
dycję wchodzi też autor Drugiego Listu św. Piotra, pisząc, że źródłem niepowtarzalnej wiary chrześcijańskiej jest właśnie Jezus Chrystus.

Z imieniem tym jest ściśle związany tytuł „nasz Pan”. Twórcy Septuaginty na miejscu świętego i niewymawialnego imienia Bożego użyli tytułu kyrios, który wskazywał na władzę Boga nie tylko nad Izraelem, ale też nad całym światem. Kościół pierwotny jednak zaczął w pewnym momencie odnosić go nie tylko do Boga, ale też do Chrystusa zmartwychwstałego, czego najbardziej znaczącym przykładem jest wyznanie wiary w Flp 2,11 i Rz 10,9. W Drugim Liście św. Piotra termin kyrios pojawia się aż 14 razy: 6 razy odnosi się do Boga $(2,9.11 ; 3,8.9 .10 .15)$, przy czym teksty w 2,9.11 i 3,10 nie są jednoznaczne (kyrios może być w nich związany zarówno z Bogiem, jak też z Jezusem Chrystusem), a w pozostałych wersetach (1,2.8.11.14.16; $2,20 ; 3,2.18)$ jest wyraźnie tytułem Jezusa Chrystusa. To pozwala zrozumieć, że Piotr mówi o Jezusie Chrystusie w taki sam sposób, jak o Bogu. ${ }^{17}$ Podobnie jak Bóg, jest On wszechmocnym Panem, który ma władzę nad wiecznym królestwem $(1,11)$, co też oznacza, że jest wiecznym Królem, a Jego autorytet we wspólnocie wierzących podkreśla dodatkowo tytuł „Władca” (despotess), użyty raz w 2P 2,1.

Według 2P 1,16-17 jednym ze źródeł wiary w Jezusa jako Pana była wizja, którą apostołowie mieli w czasie Jego przemienienia na świętej górze. ${ }^{18}$ Wtedy stali się naocznymi świadkami „Jego wielkości”. Użyty tu termin megaleiotēs, występujący bardzo rzadko w Piśmie Świętym, w Łk 9,43 oznacza wielkość samego Boga, zaś w Dz 19, 27 majestat bogini Artemidy. W tym kontekście można stwierdzić, że apostołowie, oglądając na górze przemienienia wielkość (megaleiotēs) swego Pana, mieli wizję Jego bóstwa. Piotr jest ponadto świadomy, że Jezus Chrystus otrzymał „cześć i chwałę” (timēn kai doksan 2P 1,17) od samego Boga Ojca, który uroczyście przedstawił Go jako swego umiłowanego Syna. Słowa Boga, dochodzące wówczas

17 Por. T. C a 11 a n, The Christology of the Second Letter of Peter, Biblica 82/2001, s. 255.

18 Por. P. D s c huln ig g, Der theologische Ort des Zweiten Petrusbriefes, Biblische Zeitschrift 33/1989, s. 171. 
od „wspaniałego Majestatu” Bożego, brzmiące tak samo jak Jego słowa wypowiedziane w czasie chrztu Jezusa w Jordanie (Mt 3,17), stały się dla chrześcijan punktem wyjścia do refleksji nad naturą Jezusa Chrystusa i na koniec doprowadziły pierwszych teologów apostolskich do wniosku, że Ten, który zgodnie z zapowiedziami starotestamentalnymi przyjął misję Sługi Bożego (zob. Ps 2,7; Iz 42,1), jest jedynym i umiłowanym Synem Ojca. ${ }^{19}$

Idąc śladem tych teologów, autor Drugiego Listu św. Piotra dokonuje refleksji nad niezwykłym wydarzeniem przemienienia Jezusa na świętej górze i dochodzi do wniosku, że Jego chwała jest równa chwale Boga. W tym świetle staje się zrozumiałe, dlaczego Piotr na początku swego listu nazywa Jezusa Chrystusa Bogiem (2P 1,1), a w doksologii końcowej $(3,18 b)$ sławi Go słowami, które zazwyczaj zarezerwowane są dla Boga: „Jemu chwała zarówno teraz, jak i do dnia wieczności". ${ }^{20}$ Tak wzniosłych wypowiedzi o Jezusie nie znajdziemy we wczesnych pismach nowotestamentowych. Pierwsi chrześcijanie byli głęboko zakorzenieni w monoteizmie starotestamentowym i niezachwianie wyznawali, że jedynie Pan jest Bogiem (por. Pwt 6,4; Mk 12,29). Dopiero później zaczęli zdawać sobie sprawę, że wielkość i chwała Jezusa Chrystusa są równe mocy i majestatowi jedynego Boga. Wyraźne wypowiedzi o Jego bóstwie znajdziemy zwłaszcza w Ewangelii św. Jana, gdzie autor ukazuje Go jako Słowo, które jest Bogiem (J 1,1.18), i gdzie sam Jezus naucza: „Ja i Ojciec jedno jesteśmy” (10,30); „Ojciec jest we Mnie, a Ja w Ojcu" (10,29; zob. też 1J 5,20; Hbr 1,8-12). Oznacza to, że Drugi List św. Piotra znajduje się w grupie późnych pism nowotestamentowych, które oparte są na długiej i bogatej tradycji wiary, refleksji i nauczania. ${ }^{21}$ Jego autor przekazuje na piśmie utrwaloną

19 Por. O. M i c h e 1, Figlio di Dio, w: L. C o e n e n, E. B e y r e u th e r, H. B i e t e $\mathrm{n}$ h a r d (red.), Dizionario dei concetti biblici del Nuovo Testamento, Bologna $1989^{4}$, s. 675-676.

20 Por. T. C a 11 a n, The Christology of the Second Letter of Peter, s. 255.

${ }^{21}$ Por. tamze, s. 238; R.W. W a 11, The Canonical Function of 2 Peter, Biblical Interpretation 9/2001, s. 64-81. 
już w tradycji chrześcijańskiej formułę, która zawiera przesłanie, że Jezus Chrystus jest Bogiem jako Pan i Zbawiciel (2P 1,1.11; 2,20; $3,2.18)$. Zarazem zaś daje do zrozumienia, że jest On osobą różną od objawionego w Starym Testamencie Boga, gdyż jest Jego Synem, od Niego właśnie otrzymuje cześć i chwałę (2P 1,17) i jako Syn ma tę samą naturę, co Ojciec. ${ }^{22}$

Jak zostało ukazane wyżej, w Drugim Liście Piotra Jezus Chrystus Pan jest pięciokrotnie nazwany „Zbawicielem” - sōtēr (2P 1,1.11; 2,20; $3,2.18)$. Termin ten, który w Septuagincie stanowił wręcz nazwę Boga (zob. np. Pwt 32,15; 1Mch 4,30; Mdr 16,7; Syr 51,1; Ba 4,22; 3Mch 6,29; PsSal 3,6), również w Nowym Testamencie pojawia się 8 razy w odniesieniu do Boga Ojca (Łk 1,47; 1Tm 1,1; 2,3; 4,10; Tt 1,3; 2,10; 3,4; Jud 25), ale w innych 11 tekstach jest on tytułem Jezusa Chrystusa (Łk 2,11; J 4,42; Dz 5,31; 13,23; Ef 5,23; Flp 3,20; 2Tm 1,10; Tt 1,4; $2,13 ; 3,6 ; 1 \mathrm{~J} 4,14)$. Do tej ostatniej liczby należy dodać 5 fragmentów z Drugiego Listu św. Piotra, w których termin sōtēr jest związany wyłącznie z imieniem Jezusa Chrystusa. Piotr przyjmuje ten tytuł jako coś oczywistego i nawet nie czuje potrzeby wyjaśniania go. Jedynie w 2,1 ukazuje Go jako Władcę, ,który ich [czyli tych, którzy Go odrzucają] nabył". Używa tu czasownika agoradzō, który w literaturze greckiej oznacza „wykupić” coś, „nabyć na własność”, uiszczając za to stosowną należność. Najczęściej oznacza on zakup jakiejś rzeczy, ale niekiedy może też odnosić się do kupienia sobie niewolnika. Piotr używa tego słowa w tym drugim sensie, dając do zrozumienia, że Jezus, jako Władca wiecznego królestwa (por. 2P 1,11), wykupił swych wyznawców od poprzedniego właściciela, a oni przez to stali się Jego sługami. ${ }^{23}$

Pisząc w taki sposób, Piotr nigdzie nie wyjaśnia, jak Jezus dokonał tego zakupu i jaką cenę zapłacił za nabycie swych wyznawców. Zapewne uważa, że również ta kwestia jest dobrze znana jego czytelnikom. Termin agoradzō występuje też w 1Kor 6,20; 7,23 na

22 Por. T. C a 11 a n, The Christology of the Second Letter of Peter, s. 256-259.

23 Por. t e n ż e, The Soteriology of the Second Letter of Peter, Biblica 82/2001, s. 550 . 
określenie zbawczego dzieła Chrystusa, ${ }^{24}$ jednakże nawet w tych tekstach św. Paweł nie porusza zagadnienia, komu i jaką cenę uiścił Zbawiciel, nabywając nas sobie na własność. Odpowiedź na to pytanie pojawia się tylko w Dz 20, 28 i Ap 5, 9, gdzie autorzy piszą, że Jezus Chrystus nabył sobie na własność lud wybrany swoją krwią, czyli swą męką i śmiercią na krzyżu. Można zatem przypuszczać, że w 2P 2,1 autor posługuje się tym samym symbolicznym językiem i uważa śmierć Jezusa Chrystusa za cenę, która była konieczna do nabycia przez Niego na własność swych wyznawców. ${ }^{25}$ Nigdzie jednak nie pisze wyraźnie, od czego zostali oni wykupieni. Można jedynie się domyślać na podstawie innych jego wypowiedzi, że dzięki zbawczemu dziełu Jezusa Chrystusa zostali wyrwani z niewoli zepsucia (por. 2,19), które niesie świat, i uratowani od zguby, która zagraża osobom odrzucającym Boga i Jego Prawo (por. 2,1.12). Celem tego dzieła jest natomiast udzielenie wierzącym drogocennych i największych obietnic, do których należy uczestnictwo w Bożej naturze $(1,4)$ oraz otwarcie wejścia „do wiecznego królestwa Pana naszego i Zbawcy, Jezusa Chrystusa" (1,11).

\section{Eschatologia}

To zdanie z 2P 1,11 wskazuje, że całe życie chrześcijan jest ukierunkowane eschatologicznie. Odkąd bowiem wyrwali się ,z zepsucia wywołanego na świecie żądzą" (2P 1,4), powinni na pierwszym miejscu troszczyć się o rozwój cnót, które doprowadzą do pełnego poznania Pana naszego, Jezusa Chrystusa (1,5-8), a celem tego jest ostateczne wejście do Jego „wiecznego królestwa” $(1,11)$. To królestwo natomiast wykracza poza wszelkie ramy dziejowe, także poza ramy istnienia Kościoła, który pewnego dnia skończy swe ziemskie zadanie wyznaczone mu przez Pana. Chrześcijanie, wsparci mocą Bożą,

24 Szerzej zagadnienie to przedstawia S. L y o n n e t, L'emploi paulinien de eksagoradzein au sens de „redimere” est-il attesté dans la littérature grecque?, Biblica 42/1962, s. 85-88.

25 Por. T. C a 11 a n, The Soteriology of the Second Letter of Peter, s. 550. 
pracują nad swą pobożnością i prawością życia przede wszystkim po to, by właściwie przygotować się na ostateczny dzień, w którym nastanie nowe niebo i nowa ziemia $(3,13)$. Fałszywi prorocy i heretycy, których Piotr piętnuje w swym liście, szydzili z obietnicy, którą Jezus dał swym uczniom. Tym samym popełnili błąd polegający na tym, że przestali oczekiwać Jego powtórnego przyjścia, zagubili się w sprawach codziennych i ulegli demoralizacji. ${ }^{26}$

Celem Drugiego Listu św. Piotra jest m.in. przypomnienie adresatom, że chrześcijanie zawsze powinni oczekiwać przyjścia Pana oraz Jego pełnego triumfu nad światem. O Jego powtórnym przyjściu jest już mowa w pierwszej (testamentarnej) części tego pisma, gdzie autor stwierdza: „Nie za wymyślonymi bowiem mitami postępowaliśmy wtedy, gdy daliśmy wam poznać moc i przyjście Pana naszego, Jezusa Chrystusa" $(1,16)$. Aby wykazać wiarygodność swej nauki, nie odwołuje się do Jego zmartwychwstania oraz objawień po zmartwychwstaniu, jak to czyni św. Paweł (1Kor 15,3-8.14), lecz do przemienienia, ${ }^{27}$ którego wybrani apostołowie byli naocznymi świadkami. Oświadcza tym sposobem, że już przed faktem zmartwychwstania niemal namacalnie doświadczyli oni Bożej chwały swego Nauczyciela, oraz sugeruje, że Jego przemienienie na górze świętej, w którym otrzymał „od Boga Ojca cześć i chwałę” $(1,17)$, pozwala wierzącym wyobrazić sobie, w jaki sposób dokona się Jego powtórne przyjście. ${ }^{28}$

${ }^{26}$ W tym kontekście bardzo interesujące są refleksje, które w podobnym kierunku snuje na temat życia pozbawionego wymiaru eschatologicznego S. Z e d d a, L'escatologia biblica, t. II: Nuovo Testamento (eccetto i Sinottici), Brescia 1975, s. $550 \mathrm{n}$.

27 Zauważają to m.in. J. K 1 i n g e r, The Second Epistle of Peter: an Essay in Understanding, St Vladimir's Theological Quarterly 17(1973) nr 1-2, s. 160; t e n ż e, Drugi List Świętego Piotra Apostoła, Znak 28/1976, s. 1530; M. R o s i k, Eschatologia, w: t e n ż e (red.), Teologia Nowego Testamentu, t. 3: Listy Pawłowe, Katolickie i List do Hebrajczyków, Wrocław 2008, s. 280.

28 Por. F. Gryg lew i c z, Eschatologiczne aspekty listów katolickich, w: L. S t a chow i k, R. R ub in ki ew ic z (red.), Biblia o przyszłości, Materiały pomocnicze do wykładów z biblistyki 8, Lublin 1987, s. 117. 
Temat wypełnienia się obietnicy przyjścia Pana przy końcu czasów Piotr omawia szerzej w trzeciej części swego listu (2P 3, 5-13). W tekście tym nazywa paruzję Chrystusa „dniem sądu” - hèmera kriseōs (w. 7), „dniem Pańskim” - hèmera kyriou (w. 10) oraz „dniem Bożym" - hèmera tou theou (w. 12). Ta terminologia jest wyraźnym nawiązaniem do proroctw starotestamentowych. Wyrażenie „dzień Pański" (jôm JHWH) zostało ukute i wprowadzone do kanonu tematów teologicznych przez proroka Amosa ${ }^{29}$ (zob. np. Am 5,18), od którego przejęli tę ideę inni prorocy, nauczając, że będzie to dzień gniewu Pańskiego, w którym zostaną ukarane narody wrogie Izraelowi i wezwane do nawrócenia (zob. np. Iz 13; 34; Ab 15-18; So 2,3-15; 3,9-10), reszta Izraela zaś po swych klęskach zostanie odbudowana i przywrócona do dawnej świetności (J1 3,5; Am 5,1-17; Ab 19-21; So 3,11-18; Za 12,1-6 i inne). ${ }^{30} \mathrm{~W}$ ich wypowiedziach zatem dzień Pański oznacza gwałtowną interwencję Boga w historię narodu wybranego i innych ludów ziemi, której owocem jest oczyszczenie ich z nieprawości i przywrócenie sprawiedliwości. ${ }^{31}$

Początkowo prorocy wyobrażali sobie, że dzień Pański nastanie w niedalekiej przyszłości, później jednak zaczęli przesuwać go w bliżej nieokreślone czasy, aż wreszcie zaczęli mówić o odległych czasach ostatecznych, w których nastąpi definitywne objawienie Boga oraz koniec obecnego świata (zob. np. Dn 9,26; 11,27. 35; 12,12-13). Wtedy też do swych proroctw dotyczących sądu Bożego, utworzenia nowego porządku świata oraz ustanowienia wiecznego królestwa zaczęli włączać opisy przerażających zjawisk kosmicznych, które miały na celu ukazać zarówno rozmiar gniewu Boga, jak też gwałtowność

29 Por. T. Tuło d z i e c k i, Amosa Księga, w: H. W itc z y k (red.), Nowy słownik teologii biblijnej, Lublin-Kielce 2017, s. 32.

${ }_{30}$ Odnośnie do tego zob. J. S z l a g a, Elementy eschatologiczne u proroków sprzed niewoli babilońskiej, w: L. S t a c h ow i a k, R. R u b i n k i e w i c z (red.), Biblia o przyszłości, s. 22-24; J. H o m e r s k i, Perspektywy przyszłości ludu Bożego w ujęciu proroków okresu niewoli i po niewoli babilońskiej, w: tamże, s. 27-37.

31 Por. A. J a n k ow s k i, Eschatologia biblijna Nowego Testamentu, Kraków 1987, s. 26. 
i skuteczność Jego interwencji w historię świata ${ }^{32}$ (zob. So 1,15; J1 3,4; Iz 13,9-13; 24,19; 34,4; Ag 2,6; Ha 3,6). Zapowiadane przez nich zaburzenia kosmiczne, takie jak zaćmienie Księżyca i Słońca, spadające gwiazdy, trzęsienia ziemi i usunięcie firmamentu niebieskiego wskazywały na wyjątkowość działania Boga, który jest Panem natury i któremu nie może się oprzeć się żadna potęga. ${ }^{33}$

Ich obrazowy język z biegiem czasu stał się stałym elementem tekstów mających apokaliptyczny gatunek literacki. Naśladuje go również autor 2P 3,10.12, aby za jego pomocą opisać gwałtowne przeobrażenia w świecie, towarzyszące przyjściu Jezusa Chrystusa w dniu Pańskim: ${ }^{34}$ „Jak złodziej zaś przyjdzie dzień Pański, w którym niebo z szumem przeminie, gwiazdy się w ogniu rozsypią, a ziemia i dzieła na niej zostaną odnalezione”. Wówczas „niebo, płonąc, pójdzie na zagładę, a gwiazdy w ogniu się rozsypią". Analizując ten tekst, wielu egzegetów uważa, że zapowiada on rzeczywiste unicestwienie obecnego świata oraz stworzenie na jego miejscu całkowicie nowego nieba i nowej ziemi. ${ }^{35}$ Inni jednak są zdania, że tekst ten należy interpretować jako zapowiedź radykalnej odnowy

32 Por. tamże, s. 27.

33 Odnośnie do tego por. M. B e d n a r z, Czy gwiazdy będa spadać? Tarnowskie Studia Teologiczne 25(2006) nr 2, s. 36-38; M. Ł a n o s z k a, Idea odnowienia kosmosu jako obraz nadchodzącej petni królestwa Bożego, Tarnowskie Studia Teologiczne 25(2006) nr 2, s. 44-60.

${ }^{34}$ Zob. E. L övest a m, Eschatologie und Tradition im 2. Petrusbrief, w: W. We in r i h (red.), The New Testament Age. Fs. B. Reicke, Macon 1984, s. 287-300.

35 Zob. m.in. J.W. R o b e r t s, A Note on the Meaning of II Peter 3:10d, Restoration Quarterly 6/1962, s. 32-33; R.L. O v e r s t r e e t, A Study of 2 Peter 3:10-13, Bibliotheca Sacra 137/1980, s. 362-365; J.H. N e y r e y, 2 Peter, Jude. A New Translation with Introduction and Commentary, The Anchor Bible 37C, New York 1993, s. 243; J. M a c A r t h u r, 1 and 2 Peter and Jude, MacArthur New Testament Commentary 30, Chicago 2005, s. 124-125; B. R o s s in g, Hastening the Day When the Earth Will Burn: Global Warming, 2 Peter, and the Book of Revelation, w: C. B r ig g s $\mathrm{K}$ it t r e d g e i in. (red.), The Bible in the Public Square: Reading the Signs of the End Times, Minneapolis 2008, s. 30-33. 
i przeobrażenia starego wszechświata, które dojdzie do skutku w dniu sądu. ${ }^{36}$ Uważają oni, że Piotr, pisząc o przemijaniu nieba oraz posługując się obrazem potopu i ognia, pragnie przede wszystkim pouczyć swych czytelników, że Bóg zamierza w czasach ostatecznych oczyścić niebo i ziemię, swe „dobre” (por. Rdz 1) stworzenie, ze skutków grzechu i przemienić je w nowe niebo i nową ziemię, „w których zamieszka sprawiedliwość" (2P 3,13).

Zawarta w 2P 3,13 idea nowego nieba i nowej ziemi (występująca też w Ap 21,1) została zaczerpnięta z proroctwa Iz 65,17, w którym Bóg mówi: „Bo oto Ja stwarzam nowe niebiosa i nową ziemię; nie będzie się wspominać dawniejszych dziejów ani na myśl one nie przyjdą”. Te dwie frazy: „nowe niebiosa i ziemia nowa” oraz „dawniejsze dzieje" wprowadzają rozróżnienie na poziomie jakościowym między dwoma kosmicznymi porządkami. Rzeczywistość określana jako „dawniejsza” (w LXX jest ona nazwana przymiotnikiem proteros - ,pierwsza”, „,pierwotna”) była skażona złem oraz charakteryzowała się nietrwałością i tymczasowym istnieniem; natomiast rzeczywistość określana jako „nowa” (kainos) będzie całkowicie oczyszczona ze zła i trwała, gdyż będzie stanowiła niepodzielną własność Boga. ${ }^{37}$ Ta sama idea jest obecna w 2P 3,13. Autor tego tekstu zapewnia swych czytelników, że jak starożytny świat, zniszczony przez potop (por. 2P 2,5; 3,6), dał początek obecnemu porządkowi, tak też w czasach ostatecznych Bóg osądzi obecny świat, aby wprowadzić go w rzeczywistość nowego stworzenia. ${ }^{38}$

36 Tak uważają np. G. He i d e, What Is New about the New Heaven and the New Earth? A Theology of Creation from Revelation 21 and 2 Peter 3, Journal of the Evangelical Theological Society 40/1997, s. 40; R.A. R e e s e, 2 Peter and Jude, s. 218; G.L. G r e e n, Jude and 2 Peter, s. 334-335; P.H. D a v i d s, The Letters of 2 Peter and Jude, s. 157; E. A d a m s, Does Awaiting "Hew Heavens and a Hew Earth" (2 Ret 3.13) Mean Abandoning the Environment?, Expository Times 121/2010, s. 171; M.Y. E m e r s o n, Does God Own a Death Star? The Destruction of the Cosmos in 2 Peter 3:1-13, Southwestern Journal of Theology 57/2015, s. 285-293.

37 Por. M. Ła n o s z k a, Idea odnowienia kosmosu jako obraz nadchodzacej petni królestwa Bożego, s. 52-53.

38 Por. G.L. G r e e n, Jude and 2 Peter, s. 334. 
Aby właściwie rozumieć 2P 3,5-18, należy stwierdzić, że apokaliptyczne opisy kosmicznych kataklizmów, towarzyszących przyszłemu sądowi Bożemu nad światem, są tylko drugorzędnym elementem tego tekstu, istotne znaczenie natomiast mają w nim pozytywne wnioski, dotyczące moralnego życia chrześcijan (ww. 11.14.17-18a). Z obrazów przemijania tego świata Piotr wyciąga bowiem wniosek, że oczekiwanie nowej rzeczywistości powinno przenikać i kształtować całe doczesne życie chrześcijan. ${ }^{39}$ Pisząc jednak o tym oczekiwaniu, przyznaje, że nieco się ono przedłuża. Niektórzy nawet zaczęli się niecierpliwić faktem, że przeminęło pokolenie ojców $(2 \mathrm{P} 3,4 \mathrm{~b})$ i nie wydarzyło się nic, co by zapowiadało bliską paruzję Chrystusa. Inni z kolei zaczęli wręcz szydzić z wiary w powtórne przyjście Pana i dokonanie się sądu nad światem (w. 3-4a). Polemizując z nimi, Piotr jako jeden z ostatnich autorów nowotestamentowych usiłuje wzmocnić eschatologiczne oczekiwania członków Kościoła oraz nadzieje na przemianę świata doczesnego i nadejście nowej rzeczywistości. ${ }^{40}$ Wyjaśnia zarazem, że „Nie zwleka Pan z wypełnieniem obietnicy (...) ale On jest cierpliwy w stosunku do was. Nie chce bowiem niektórych zgubić, ale wszystkich doprowadzić do nawrócenia" (w. 9). To opóźnianie się paruzji jest więc tylko pozorne, w gruncie rzeczy bowiem Bóg, jako Pan czasu i historii (por. w. 8), wie najlepiej, kiedy dokonać interwencji w świecie. Co więcej, jest On Bogiem cierpliwym i miłosiernym, dlatego nie chce, aby Jego przyjście miało dla ludzi zgubne skutki, lecz we wszystkim, co czyni, pragnie nieść im dar zbawienia.

39 Odnośnie do tego zob. J.M. M o n for t e, Escatología y esperanza activa en 2 Pt 3,3-15, w: J.M. C a s c i a r o (red.), Esperanza del hombre y revelación bíblica. XIV Simposio Internacional de Teología de la Universidad de Navarra, Pamplona 1996, s. 165-179.

${ }^{40}$ Szerzej na ten temat pisze D. v o n A $11 \mathrm{~m} \mathrm{e} \mathrm{n,} \mathrm{L'apocalyptique} \mathrm{juive} \mathrm{et} \mathrm{le}$ retard de la parousie en II Pierre 3:1-13, Revue de Theologie et Philosophie 16/1966, s. 255-274. 


\section{Nauczanie etyczne}

Jednym z wielkich zagrożeń, przed którym stanęli adresaci Drugiego Listu św. Piotra, był niemoralny styl życia fałszywych proroków. Odrzucając władzę Jezusa Chrystusa nad sobą (2P 2,1) oraz szydząc z Jego powtórnego przyjścia w celu dokonania sądu nad światem (3,3-4), głosili zarazem wolność od wszelkich ograniczeń moralnych $(2,19)$ i złudnymi obietnicami pociągali za sobą wielu nieutwierdzonych w wierze chrześcijan $(2,2)$. Piotr w bardzo dosadny sposób pokazuje, w czym wyrażało się ich niemoralne postępowanie. Pisze o stosowanych przez nich oszustwach $(2,2.14 .18)$, o chciwości (2,3.14), bluźnierstwach i oszczerstwach (2,10b.12), o nieokiełznanej rozpuście (2,2.13.18), o oczach kobiety cudzołożnej pełnych i nienasyconych grzechem $(2,14)$. Jest możliwe, że w swej naganie posługuje się często stosowaną przez Żydów hiperbolą i wyolbrzymia niemoralne czyny heretyków, nie da się bowiem oddzielić polemicznej retoryki Piotra od rzeczywistego stanu ich moralności, który nie jest nam znany. Na płaszczyźnie teologicznej ważne jest jednak nie to, czy jego opis w pełni odpowiada faktycznej postawie fałszywych proroków, lecz o jaką moralność troszczy się autor listu, który można nazwać płomienną apologią etyki wczesnochrześcijańskiej. ${ }^{41}$

Piotr bowiem w swym liście nie tylko demaskuje i piętnuje niemoralne czyny i postawy heretyków, lecz daje też pozytywną wykładnię moralności chrześcijańskiej. Podkreśla przede wszystkim, że chrześcijanie powinni całe swe życie duchowe opierać na nauce apostołów, co w konsekwencji oznacza, że ich wiara i moralność muszą odznaczać się posłuszeństwem tej nauce, ${ }^{42}$ a moralność powinna konsekwentnie wypływać z ich wiary. Idąc po tej linii, już na początku posługuje się znanym w greckiej literaturze filozoficznej

41 Por. R.L. W e b b, The Rhetoric of 2 Peter: An Apologia for Early Christian Ethics (and not "Primitive Christian Eschatology"), w: D. B u r n s, J.W. R o g e r s o n (red.), Far for Minimal. Fs. Ph.R. Davies, London-New York 2012, s. 11-14.

${ }_{42}$ Por. H. L a ng k a m m e r, Etyka Nowego Testamentu, Wrocław 1985, s. 205-206. 
i biblijnej gatunkiem literackim, nazywanym katalogiem cnót, ${ }^{43}$ i wyjaśnia, jakie cechy powinny charakteryzować wierzących w Jezusa Chrystusa: cnota, poznanie, opanowanie, wytrwałość, pobożność, braterska życzliwość, braterska miłość (2P 1,5-7). Niektóre tych terminów („cnota” - aretē, „opanowanie” - enkrateia, ,pobożność” eusebeia) można częściej znaleźć w dziełach pogańskich filozofów greckich, zwłaszcza stoickich, niż chrześcijańskich, inne jednak należą do ważnych, a nawet centralnych tematów nowotestamentowych: „wytrwałość” - hypomone, „braterska życzliwość” - filadelfia, „miłość” - agapē. Fakt ten może sugerować, że Piotr podaje jedynie przykładową listę wartości moralnych, z których jedne były powszechnie uznawane w świecie greckim, inne zaś odgrywały fundamentalną rolę w ewangelicznym nauczaniu Jezusa i jego apostołów. ${ }^{44}$ Tym sposobem zachęca on również do rozwijania tego, co w moralności hellenistycznej było dobre i szlachetne, a zarazem przypomina im normy moralne, które są związane z przekazaną im wiarą (1,1), jak też z ich powołaniem i wyborem (1,10a).

U podstaw chrześcijańskiego życia każdego człowieka znajduje się powołanie, wraz z którym Bóg udzielił wszelkich darów potrzebnych do rozwijania w sobie wiary i pobożności oraz stania się uczestnikiem Bożej natury (1,3-4). Ci jednak, którzy uwierzyli w Jezusa Chrystusa, nie mogą zadowolić się jedynie świadomością otrzymanej od Niego łaski zbawienia, ale muszą z nią współpracować. Dlatego Piotr wzywa ich, by dołączyli do swej wiary wszelkie cnoty $(1,5)$, dzięki którym ich poznanie Jezusa Chrystusa nie będzie bezowocne $(1,8)$. Warto tu zauważyć, że na określenie „dołączenia” („dodania”) Piotr w 1,5 posługuje się czasownikiem epichorēgeō, który w środowisku greckim miał specyficzne znaczenie. Był on m.in. związany

43 Szerzej zob. A. V ö g t l e, Die Tugend- und Lasterkataloge im Neuen Testament: exegetisch, religions- und formgeschichtlich Untersucht, Aschendorff 1936; S. W i b b i n g, Die Tugend- und Lasterkataloge im Neuen Testament, Münster 1964.

44 Zob. J.D. C h a r l e s, Virtue Amidst Vice: The Catalog of Virtues in 2 Peter 1, Journal for the Study of the NT. Supplement Series 50, Sheffield 1997, s. 138-148; t e $\mathrm{n} \dot{z} \mathrm{e}$, The Language and Logic of Virtue in 2 Peter 1:5-7, Bulletin for Biblical Research 8/1998, s. 64-70. 
ze sponsorowaniem ówczesnych teatrów, gdzie często występowały duże i kosztowne chóry. Aby organizatorzy mogli pokryć koszt ich występu, potrzebna była finansowa pomoc zamożnego dobroczyńcy, którego nazywano chorēgos. Sytuacja ta pomaga lepiej zrozumieć tekst $2 \mathrm{P} 1,5$, chodzi w nim bowiem nie o to, że wierzący mają zwyczajnie „dołączać” poszczególne cnoty do przekazanej im wiary, jak się dokłada kolejne paciorki w naszyjniku, lecz o to, że muszą mieć swój osobisty wkład we własny rozwój moralny. ${ }^{45}$ Gdy zaś do otrzymanej od Boga łaski dodadzą swój wysiłek, swą pracę nad osiągnięciem cnót świadczących o ich wewnętrznej szlachetności, wtedy Bóg jeszcze wystąpi z inicjatywą zbawczą, tak że zostanie bogato udzielony (epichorēgoumenon) dar wejścia do wiecznego królestwa (1,11), w którym będzie można spotkać swego Dobroczyńcę i Zbawiciela, Jezusa Chrystusa.

Temat ten powraca w końcowej części 2P, gdzie autor ponownie zachęca chrześcijan, by w spokojnym oczekiwaniu na powtórne przyjście Jezusa Chrystusa dołożyli ze swej strony wszelkich starań, aby On znalazł ich „,bez plamy i skazy” $(3,14)$. Powinni oni zatem nie tylko czynnie i z czujnością oczekiwać dnia paruzji, ale też na co dzień żyć nadzieją oraz przez całe swe życie uczyć się cnót, które są widoczne u Boga w Jego relacji do ludzi i które świadczą o Jego świętości, moralnej doskonałości i nieskazitelności. ${ }^{46}$ Tylko wtedy pozbędą się wszystkiego, co w dniu sądu mogłoby skazić ich szlachetność i z powodu czego zasługiwaliby na naganę ze strony sprawiedliwego Sędziego.

45 Por. tamże, s. 72.

46 Por. J.M. Mo n for t e, Escatología y esperanza activa en 2 Pt 3,3-15, s. 175; W. Corbin-R e u s ch 1 ing, The Means and End in 2 Peter 1:3-11: The Theological and Moral Significance of Theōsis, Journal of Theological Interpretation 8/2014, s. 279-280; G.L. G r e e n, Jude and 2 Peter, s. 185-186. 


$$
* * *
$$

Autor Drugiego Listu św. Piotra pisze w czasie, gdy wśród chrześcijan pojawili się fałszywi prorocy i nauczyciele (2,1-2), których błędna nauka wydawała się dla wielu bardzo atrakcyjna $(2,12.14)$ i dlatego stała się dla młodego Kościoła poważnym zagrożeniem. Ze względu na ich silne wpływy oraz niebezpieczeństwo, że wielu nieutwierdzonych w wierze i moralności pójdzie za ich przykładem, Piotr ostro piętnuje ich naukę i gorszące postępowanie. Przede wszystkim jednak pisze swój list w tym celu, by przypomnieć chrześcijanom przekazaną im niegdyś naukę apostolską, w której są zawarte fundamenty wiary i moralności chrześcijańskiej: autorytet Pisma Świętego, chrystologię, soteriologię, eschatologię oraz zasady życia zgodnego z Ewangelią. Zapoznanie się z tymi tematami pozwala poznać, że Drugi List św. Piotra znajduje się na bardzo zaawansowanym etapie rozwoju myśli teologicznej, a nawet można w nim dostrzec swoiste podsumowanie nauki apostolskiej i potwierdzenie jej autorytetu w Kościele Chrystusowym.

\section{ks. Franciszek MICKIEWICZ SAC}

Słowa kluczowe: Drugi List św. Piotra; chrystologia; soteriologia; eschatologia; autorytet Pisma Świętego; życie moralne chrześcijan

Keywords: Second Letter of Saint. Peter; Christology; soteriology; eschatology; the authority of the Holy Bible; moral life of Christians

\section{The main theological themes of the Second Letter of St Peter Summary}

The author of the Second Letter of St Peter wrote at a time when there were false prophets and teachers among Christians, whose erroneous learning seemed very attractive to many, and therefore became a serious threat to the young Church. Because of their strong influence and the danger that many who were unstable in faith and morals would follow their example, Peter sharply denounced their teaching and scandalous conduct. Above all, however, he wrote his letter to remind Christians of the apostolic teachings 
they once gave them. This article presents the main theological topics that are the content of the teaching of the author of the Second Letter of St Peter: the divine authority of Jesus Christ (Christology), the salvific will of God and Jesus Christ (soteriology), the promise of the Lord's second coming (eschatology), the authority of the Holy Scriptures and its proper interpretation, and moral life based on the Gospel. 